\title{
慢性腎不全血清中のアルブミン結合物質の分析
}

馬㴊 非砂夫 丸山圭史 垣内孟 青木 正*
中橋 弥 光*
西陣病院内科 同泌沓器科*

key words : endogenous ligand, uremic toxin, drug-binding inhibitor

〈要旨〉

酸性および中性薬物の血清蛋白への結合能が低下する現奥は，慢性腎不全 (CRF) において広く認められている。私 共は，3-carboxy-4-methyl-5-proryl-2-furanpropanoic acid (CMPF) が, CRF 血清中の主要な内因性蛋白結合物質 であり，薬物の蛋白結合阻害物質であると報告してきた。しかしながら，CRFで認められる低アルブミン血症を考慮 にいれても，CMPF 単独では，CRF で観察されるのと同程度のフェニトインの蛋白結合低下は in vitro で再現でき ず,他の因子の関与が推測される。光こで今回，正常および CRF 血清よりリン酸緩衝液, pH 7.4 を溶離液として用 いる条件下でアルブミンを分離し，光れに結合しているアルブミン結合物質の分析を試みた。乥の結果，アルブミン に結合している主要な強い結合物質は, artifact と考えられるものを除くと, CMPF のみであった。このことより， アルブミンへの親和性の比較的小さい薬物の血清蛋白結合阻害には，インドキシル硫酸のような，弱い結合物質もあ る程度関与しているものと考えられた。

\section{Analysis of albumin-binding substances retained in chronic renal failure}

Hisao Mabuchi, Yoshifumi Maruyama, Takeshi Kakiuchi, Tadashi Aoki*, Hisarnitsu Nakahashi* Department of Internal Medicine and Department of Urology*, Nishijin Hospital

The decreased binding of anionic drugs to serum protein in chronic renal failure (CRF) is now well documented. We previously reported that 3-carboxy-4-methyl-5-propyl-2-furanpropanoic acid (CMPF) is a major endogenous protein binding substance and a drug-binding inhibitor retained in CRF serum. CMPF inhibits phenytoin and dyes binding to serum protein and serum albumin at the concentrations usually observed in CRF serum. Taking into consideration the hypoalbuminemia usually observed in CRF however, CMPF does not entirely account for the impaired phenytoin binding found in CRF serum. This observation suggests the presence of other drug-binding inhibitors, not yet identified, in CRF serum. In this study, we separated serum albumin from normal and CRF sera by fast protein liquid chromatography (FPLC) and ligand affinity chromatography (LAC) using phosphate buffer, $\mathrm{pH}$ 7.4, as an eluent, and analyzed the albumin-binding ligands by reversed-phase high performance liquid chromatography (HPLC). The HPLC peak having the highest UV absorbance was only CMPF in both samples obtained from FPLC and LAC. Weak albumin-binding substances such an indoxyl sulfate were not detected. These results indicate that the only major potent albumin-binding substance may be CMPF and that retention of other potent binding substances is scarce in CRF serum. These observations suggest that the weak binding substances retained in CRF serum contribute to a certain extent to the inhibition of protein binding observed for some drugs in CRF.

\section{緒言}

血清アルブミンは，酸性抒よび中性薬物の血液中での carrier proteinであることが知られている。そして一般
的に，これらの薬物の薬理作用は血清アルブミンに結合 していない部分，すなわちフリー分画が receptor に結合 することで発揮される。それ故，薬理作用はフリー分画

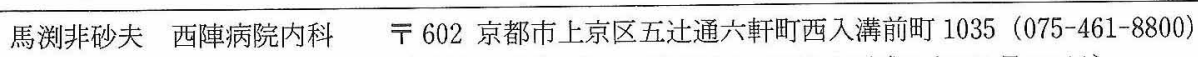

〔受付: 平成 2 年 11 月 22 日, 受理: 平成 2 年 12 月 26 日〕 
表 1 Fast protein liquid chromatograpy

Column : Superose 12 HR 10/30 (Pharmacia)

Elution buffer: $1 / 15 \mathrm{M}$ phosphate buffer, $\mathrm{pH} 7.4$

Flow-rate : $0.3 \mathrm{~m} l / \mathrm{min}$

Detection : UV $280 \mathrm{~nm}, 0.64$ AUFS

Sample : 4-fold diluted serum, $200 \mu l$

の程度に依存していると考えられている。

慢性腎不全 (CRF) では，これらの楽物と血清アルブ ミンとの結合が低下する現象，方なわちフリー分画の增

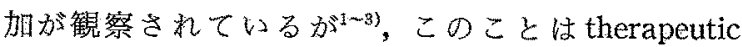
range の血中薬物濃度であっても, CRFにおいては副作 用発現の可能性があることを示唆し，䍌床上重要な現象 と考光られる。これまでの研究で，この現象は警不全血 清中に蓄積した内因性蛋白結合物質が，アルブミン楽物 結合部位で薬物の結合を競合的に阻害するためと考光ら れている3). 種々の内因性物嘖が蛋白結合阻害物賀とし

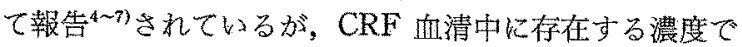
結合阻害作用が証明されているのは，私共の報告したつ ラン環化合物, 3-carboxy-4-methyl-5-propyl-2-furanpropanoic acid (CMPF) のタである8,。しかしながら， CMPF 単独では, CRF 血清中で観察されるのと同程度 の phenytoin 結合低下を in vitroで再現することはでき ない。このことから, CRF 血清中には CMPF 以外の蛋 白結合阻害物質の蓄積が推定された ${ }^{10)}$ 。そこで今回私共 は, CRF 血清からリン酸緩衝液, $\mathrm{pH} 7.4$ を溶離液とし て用いる条件下で血清アルブミンを分離し，それに結合 している物質を高速液体クロマト法 (HPLC) にて分析 し, CMPF 以外の強い蛋白結合物質の有無について检討 したので報告する。

\section{対象および方法}

桖清アルブミンは，薬物の投与を受けていない，5症 例の慢性透析患者と 3 例の健常人の血清より分離した。

アルブミンは, superose 12HR10/30 column (Pharmacia）用いる fast protein liquid chromatography と,アルブミンに特異性を有する色素である Cibacron blueF3GA を結合したゲル，AF-blue Toyopearl MH (Tosoh) を用いる ligand affinity chromatography の 2 方法で分離した（表 1,2$)$.

これらの方法で分離したアルブミンは，トリフルオロ 眽酸を終濃度が $15 \%(\mathrm{~V} / \mathrm{V})$ になるよう加光，結合物質 を遊離さ世た後除去し，そして上清を Sep-pak $\mathrm{C}_{18}$ にア プライし， $10 \mathrm{~m} l$ の蒸留水で洗浄後， $3 \mathrm{~m} l$ のエ夕ノ一ル で溶出した。

分離したアルブミン結合物質は，すでに報告した逆相 HPLC 法 ${ }^{10)}$ にて分析した. HPLC ピータのUVスペタ
表 2. Ligand affinity chromatography

Column : AF-Blue Toyopearl MH $(0.82 \times 10 \mathrm{~cm})$

Binding buffer (A) : 1/15 M phosphate buffer, $\mathrm{pH} 7.4$

Eluting buffer (B) : 1/15 $\mathrm{M}$ phosphate buffer, $\mathrm{pH} 7.4$ $+2 \mathrm{M} \mathrm{KCl}$

Flow-rate $: 1.5 \mathrm{ml} / \mathrm{min}$

Detection: UV $280 \mathrm{~nm}, 1.24$ AUFS

Sample: Serum, $1 \mathrm{~m} l$

トルは, SPD-MIA photodiode array UV-VIS spectrophtometer (島津) を用いて on-line で記録した。

結果

図1，2にそれそれ fast protein liquid chromatogra-

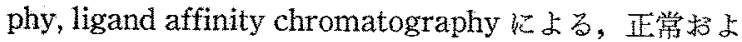
び透析患者血清汃らのアルブミン分離のクロマトグラム を示す．アルブミン分画を分取し，アルブミン結合物質 を逆相 HPLC にて分析したが, 図 3 亿 fast protein liquid chromatography, 図 $4 k$ ligand affinity chromatography にて得たサンプルのクロマトグラムを 示す、各々の CRF サンプルのクロマトグラムで，最も 強いUV 吸收を呈するピークは, 保持時間とUV スペ クトル (data not shown) より CMPF と同定されたが, 弱い結合物質である,インドキシル硫酸, 馬尿酸, イン ドール酷酸などに相当するピークは検出されなかった。 また，図 4 の正常抢よび CRF サンプルで認められる, 保持時間約 24 分のピークは artifact と考兄られた。 は ずれの方法で分離された CRF 血清のサンプルも, 逆相 HPLC 法にて, CMPF の近傍に有意なピークを検出し たが，同定はできなかった。

考察

CMPF は CRF 血清中に認められる濃度で, in vitro や薬物や色素の血清アルブミンへの結合を阻害し，血液 透析では除去されず, hemoperfusion や plasmapheresis でしか除去されない強い蛋白結合物質である かしながら，CRF 血清で認められる phenyoin の結合低 下は，CRFに扔いて一般的に観察される低アルブミン血 症を考慮にいれても, CMPF 単独では説明できず, 他の 因子の関与が推測される 常血墏へ馬尿酸とインドキシル硫酸を単独あるい怯に 加えても，尿毒症血墏で観察される，サリチル酸の血獎 蛋白結合低下の 15\%程度しか説明できないと報告し，他 の結合阻害物質の存在を示唆している。そこで，現在ま でに検出されていない，CMPF に匹敵する強い結合物質 の存在の可能性飞ついて今回検討した。

今回用いたアルブミン分離法は，溶離液にリン酸緩衝 液，pH 7.4 を用いる温和な条件下であるが，弱い結合物 

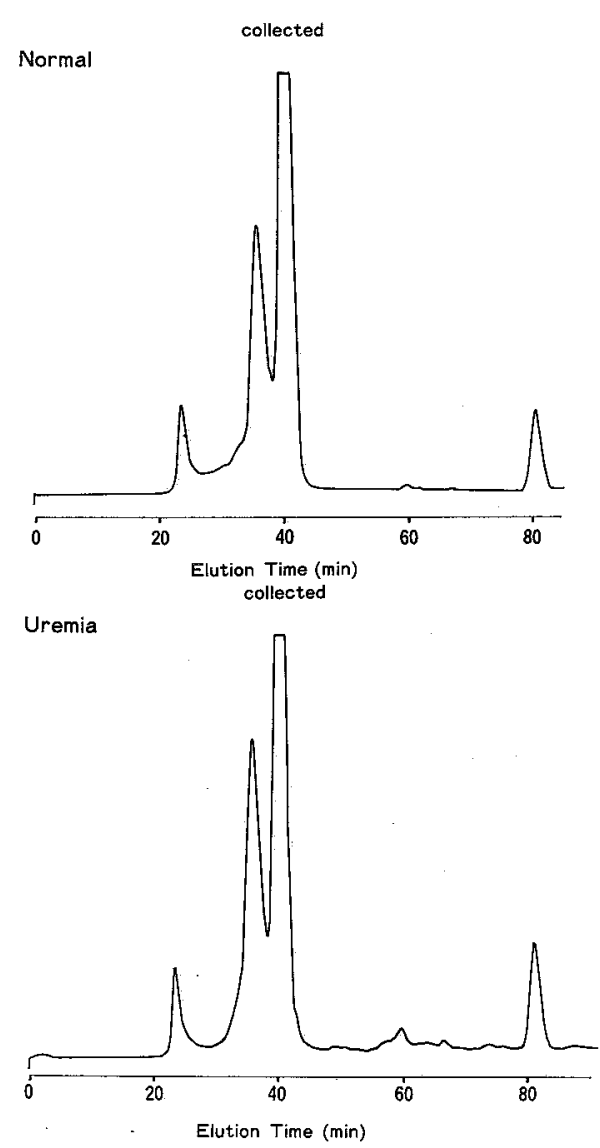

図 1 Typical chromatograms of fast protein liquid chromatography. Albumin fractions collected as marked.
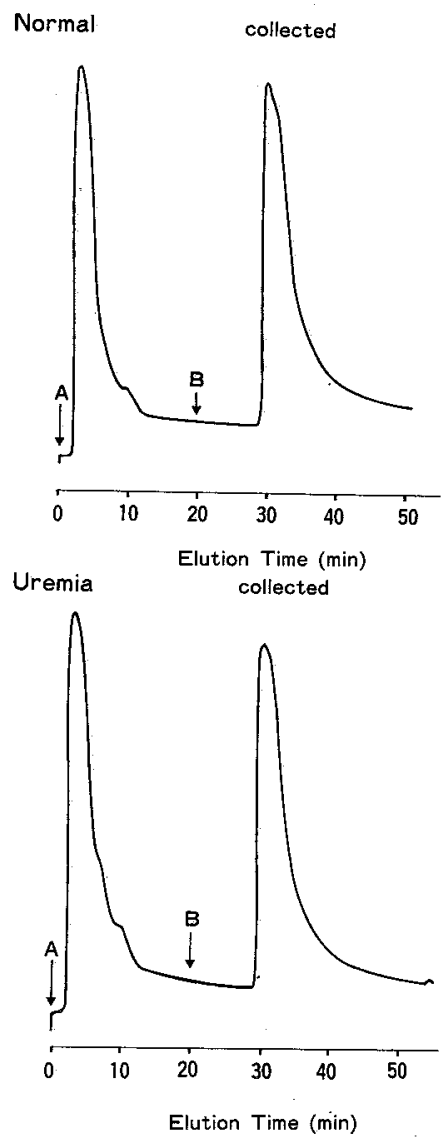

図 2 Typical chromatograms of ligand affinity chromatography. Albumin fractions collected as marked.
質であるインドキシル硫酸や馬尿酸などが検出しえな かったのは，分離操作がアルブミンの結合能に影響を与 えている可能性を否定できない. 殊に ligand affinity chromatography では, 溶離液に $2 \mathrm{M} \mathrm{KCl}$ を添加してい るので, 血清中に比して高いイオン強度となっている。 しかし CMPF が検出されたことから，CMPF に匹敵す る強い結合物磒は操作中に失われず, 検出され得ると推 測される。このことより, CRF サンプルで検出したピー クは強いアルブミン結合物質と推測されるが, CMPF と その近傍に溶出するピーク以外は，極めて微量しか蓄積 していないものと推測された。また, CMPF 近傍に溶出 するピークも, CRF 血清のエタノール除蛋白上清を直 接, 逆相 HPLC 法で分析 ${ }^{10)}$ しも検出されず, artifact のピークである可能性が強い. CMPF は，いずれのアル ブミン分離法にても dominant なピークとして検出され ることより，アルブミンへの親和性が最も強く，かつ $\mathrm{CRF}$ 血清中に蓄積する, 主要な強い結合阻害物質と考光
られた。

私共は, 血清アルブミンを ligand とする, high-performance affinity chromatography $そ$, CRF 血清中に 蓄積するアルブミン結合物質を分離し，今回と同じ逆相 HPLC 法にて分析したが，その際には CMPF 以外の dominantなピークを検出した ${ }^{10)}$ 。しかしそのピークは, 今回の CMPF 近傍に溶出するピークと同様に，除蛋白 血清サンプルの直接分析の結果からは有意なピークとは 考えがたく，そのピークの意義についても不明である。

以上のことより, 今回の方法にて検出しえない比較的 アルブミンに強い親和性を有する結合物質の存在を完全 に注否定できないが，腎不全血清中で観察される薬物結 合阻害には, CMPF を中心とし，それ以外は微量にしか 蓄積していない強い結合物質のみでなく，インドキシル 硫酸を代表とする弱い結合物質も関与している可能性が 推測される。無論, 個々の薬物のアルブミンへの親和性 の強弱に，これらの内因性結合物質の関与は依存してい 

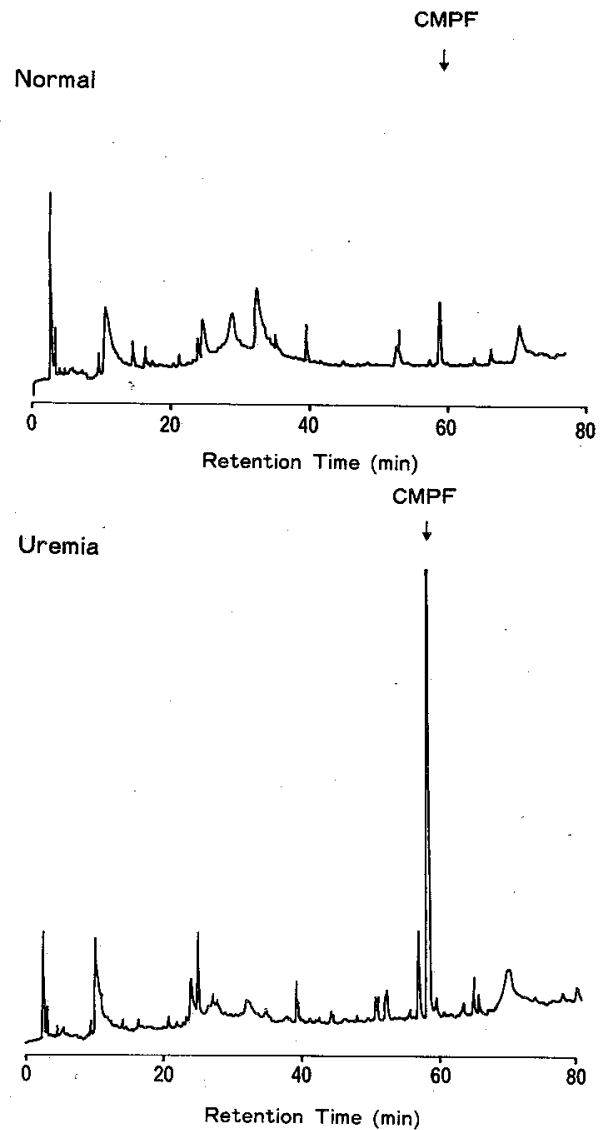

図 3 Reversed-phase HPLC of samples obtained from fast protein liquid chromatography. Arrows indicate the elution position of authentic CMPF.

\section{るものと考えられる。}

薬物を CRF 血清へ添加することにより, 内因性蛋白 結合物質のアルブミン結合能を低下せしめることは可 能 ${ }^{14)}$ であり, diazepam はインドキシル硫酸, インドール 酢酸，馬尿酸の結合を阻害し，warfarin はこれらに加え て, CMPF の結合も阻害する. CMPF は, warfarin の


薬物と内因性蛋白結合物質との相互作用が, CRF におい て認められる, 薬物の血清蛋白への結合が低下する現象 の機序ではないかと推測される。

CMPF を中心とする強い結合物質と弱い結合物質と の，個々の薬物の結合阻害現象における synergism につ いては，今後検討の予定である。

\section{結語}

1。リン酸緩衝液，pH 7.4 を溶離液として用いる fast protein liquid chromatography, ligand affinity chromatography で分離した腎不全血清中のアルブミン
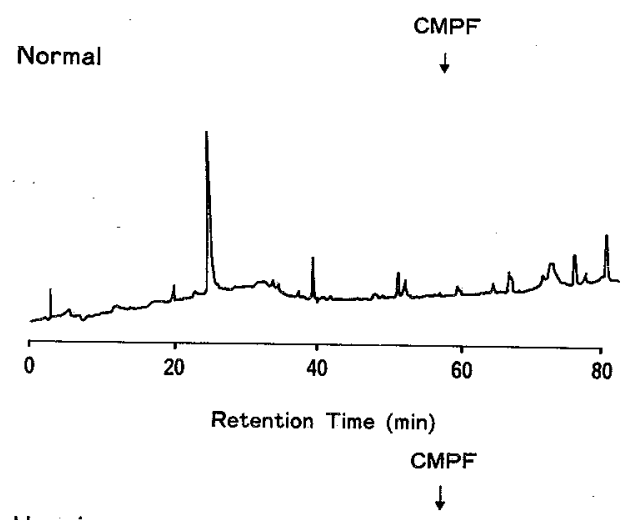

Uremia



図 4 Reversed-phase HPLC of samples obtained from ligand affinity chromato graphy. Arrows indicate the elution position of authentic CMPF.

に結合している主要な強い結合物質はフラン環化合物の みであり,他の強い結合物質の蓄積は微量と考元られた。

2。以上のことより，薬物によってはインドキシル硫 酸などの弱い結合物質も，腎不全血清中で認められる， 薬物の血清蛋白結合低下に関与している可能性が推測さ れた.

本論文の要旨は第 35 回日本透析療法学会総会 (横浜，1990 年 7 月）に扔いて発表した。

\section{文献}

1) Reidenberg MM, Odar-Cederlöf I, vonBahr C, Borga O, Sjöquist F : Protein binding of diphenylhydantoin and desmethylimipramine in plasma from patients with poor renal function. N Engl J Med $285: 264-267,1971$

2) Reidenberg MM : The binding of drugs to plasma 
proteins and the interpretation of measurements of plasma concentrations of drugs in patients with poor renal function. Am J Med 62: 466-470, 1977

3) Gulyassy PF, Depner TA : Impaired binding of drugs and endogenous ligands in renal diseases. Am J Kidney Dis 2 : 578-601, 1983

4) Bowmer CJ, Lindup WE : Decreased drug binding in uraemia : Effect of indoxylsulphate and other endogenous substances on the binding of drugs and dyes to human albumin. Biochem Pharmacol $31: 319-323,1982$

5) Lichtenwalner DM, Suh B, Lichtenwalner MR : Isolation and chemical characterization of 2hydroxybenzoylglycine as a drug binding inhibitor in uremia. J Clin Invest $71: 1289-1296$, 1983

6) Ikeda $\mathrm{K}$, Yoshitomi H, Nakayama $T$, Goto $\mathrm{S}$, Kimura $\mathrm{T}$ : Plasma protein binding of frusemide in renal failure rabbits: Investigation of endogenous protein binding inhibitors. J Pharm Pharmacol 36 : 663-667, 1984

7) Gulyassy PF, Bottini AT, Stanfel LA, Jarrard EA, Depner TA : Isolation and chemical identification of inhibitors of plasma ligand binding. Kidney Int 30:391-398, 1986

8) Mabuchi $\mathrm{H}$, Nakahashi $\mathrm{H}$ : Isolation and characterization of an endogenous drug-binding inhibitor present in uremic serum. Nephron $44: 277$ $-281,1986$
9) Mabuchi H, Nakahashi $H:$ A major inhibitor of phenytoin binding to serum protein in uremia. Nephron $48: 310-314,1988$

10) Mabuchi $H$, Nakahashi $H$ : Separation of albumin-binding ligands present in uremic serum by high-performance affinity chromatography. J Chromatogr 529 : 424-430, 1990

11) Mabuchi $H$, Nakahashi $H$ : Determination of $3-$ carboxy-4-methyl-5-propyl-2-furanpropanoic acid, a major endogenous ligand substance in uremic serum, by high-performance liquid chromatography with ultraviolet detection. J Chromatogr 415:110-117, 1987

12) Mabuchi $H$, Nakahashi $H:$ A major endogenous ligand substance involved in renal failure. $\mathrm{Ne}$ phron $49: 277-280,1988$

13) Gulyassy PF, Jarrard EA, Stanfel LA : Contribution of hippurate, indoxyl sulfate, and o-hydroxy hippurate to impaired ligand binding by plasma in azotemic humans. Biochem Pharmacol 24: 4215 $-4220,1987$

14) Mabuchi H, Nakahashi H : Displacement by anionic drugs of endogenous ligands bound to albumin in uremic serum. Ther Drug Monit 10 : 261-264, 1988

15）馬㴊非砂夫，青木 正，垣内 孟，中橋弥光：慢性 腎不全血清中の内因性蛋白結合物質に関する研究. 日腎誌 $31: 563-564,1989$ 